九州大学学術情報リポジトリ

Kyushu University Institutional Repository

\title{
Effect of Plant Hormones on Tobacco Mosaic Virus Concentration in Tobacco Tissue Culture
}

Omura, Toshihiro

Laboratory of Plant Pathology, Faculty of Agriculture, Kyushu University

Wakimoto, Satoshi

Laboratory of Plant Pathology, Faculty of Agriculture, Kyushu University

https://doi.org/10.5109/23667

出版情報: 九州大学大学院農学研究院紀要. 22 (4)，pp.211-219，1978-07. Kyushu University バージョン：

権利関係 : 


\title{
Effect of Plant Hormones on Tobacco Mosaic Virus Concentration in Tobacco Tissue Culture
}

\author{
Toshihiro Omura and Satoshi Wakimoto \\ Laboratory of Plant Pathology, Faculty of Agriculture, \\ Kyushu University 46-01, Fukuoka 812 \\ (Received February 3, 1978)
}

\begin{abstract}
Tobacco mosaic virus (TMV) concentrations in tobacco callus tissues grown on the media containing $\alpha$-naphthaleneacetic acid (NAA) and kinetin at different concentrations were assayed periodically during successive cultures. Tobacco callus originally raised from the TMV-infected tobacco stem became green and compact when serially cultured on the medium containing lower concentration (0.01-o. $1 \mathrm{mg} / \mathrm{l})$ of NAA or higher concentration $(2 \mathrm{mg} / \mathrm{l})$ of kinetin. Translucent and soft callus was obtained at higher concentration (1-40 mg/l) of NAA or lower concentration (O-O. 2 $\mathrm{mg} / 1$ ) of kinetin. Microscopic observations of the thin sectioned callus tissues revieled that the green colored compact tissue was composed of the closely associated small cells and many tracheid-like structures, while in the translucent and soft tissue, large cells were roughly arranged showing less association and no tracheidlike structure was found. TMV was maintained at high concentration in the compact callus during successive cultures, however, it was no longer detected beyond the third generation (90 days) in the translucent soft callus grown under the optimum hormone balances. Since both hormones do not have direct inactivation effect on TMV, the results suggest that TMV multiplication in the callus tissue closely corresponds with the cell arrangement of the tissue, which is considerably affected by hormone balances in the media.
\end{abstract}

\section{INTRODUCTION}

Previous investigation provided evidence that tobacco mosaic virus (TMV) concentrations in the growing tobacco callus tissue were different depending on the type of the tissue (Omura, 1978). Various calli different in appearance were known to be obtained by changing concentrations or balances of plant hormones in the medium. Kinetin promotes cell division of tobacco callus tissue (Miller et al., 1955). Tobacco callus becomes compact if kinetin concentration is high in the medium, while it becomes soft or friable at lower concentrations (Fossard et al., 1974; Linsmaier and Skoog. 1965; Nishiyama and Taira, 1966; Vasil and Hildebrandt, 1967). Generally, at-naphthaleneacetic acid (NAA) promotes cell enlargement in tobacco callus tissue. On the influence of these plant hormones upon virus infection and/ or multiplication, many works have been carried out by using intact systemic and local lesion hosts (Aldwinckle, 1975 ; Aldwinckle and Selman, 1967 ; Cheo, 1969 ; Daft, 1965 ; Gondo, 1953; Hariharasubramanian, 1968; Kiraly et al., 1968; Kiraly and Szirmai, 1964; Milo and Srivastava, 1969a; Nakagaki, 1971; Selman, 1964; Simons 
et al., 1972). But these results will not be applicable in the case of callus tissue. By using TMV-infected tobacco callus tissue Kutsky and Rawlins (1950) and Kutsky (1952) reported that both NAA and indolebutyric acid markedly decreased TMV concentration. Milo and Srivastava (196913) reported that TMV multiplication in tobacco pith tissue culture was strongly inhibited by cytokinin at higher concentrations $(20-200 \mu \mathrm{g} / 1)$ but increased at lower concentrations $(\mathrm{O}-2 \mu \mathrm{g} / \mathrm{l})$.

The present experiment was undertaken to make clear the effect of NAA and kinetin on TMV multiplication in the growing tobacco tissue cultures with special reference to the growth habit, type and histological observation of the tissue.

\section{MATERLALS AND METHODS}

\section{Culture media}

Murashige and Skoog (1962) medium (free from Edamin, added with 20 $\mathrm{g} / \mathrm{l}$ of sucrose and $6 \mathrm{~g} / 1$ of agar) (basal medium) supplied with $1 \mathrm{mg} / 1 \mathrm{of}$ NAA and $0.2 \mathrm{mg} / 1$ of kinetin (stock medium) was used for stock culture. In order to test the effect of plant hormones, the media containing NAA and kinetin in different concentrations were prepared and $\mathrm{pH}$ was adjusted to 5.7-5.8 with either $1 \mathrm{~N} \mathrm{NaOH}$ or $1 \mathrm{~N} \mathrm{HCl}$. Thirty ml of the medium was allotted to each $100 \mathrm{ml}$ Erlenmyer's flask, and was autoclaved at $120^{\circ} \mathrm{C}$ for $10 \mathrm{~min}$.

\section{Tobacco tissue culture}

Tobacco tissue cultures raised from TMV (ordinary strain)-infected tobacco stem (cv. Bright Yellow) have been transferred monthly on the stock medium for 70 generations in our laboratory. The dark green colored compact callus maintaining TMV at high concentration was used for the first transfer in each experiment. The pieces about $100 \mathrm{mg}$ each from translucent soft tissue of a callus were monthly transferred on the media containing NAA and kinetin at different concentrations and were incubated under continuous 3,000 lux white fluorescent light at ca. $25^{\circ} \mathrm{C}$. For growth studies, 18 calli were cultured in each experiment, and fresh weight of 10 calli selected at random were recorded at the end of each generation.

\section{Infectivity assay}

Nicotiana glutinosa was used for bioassay of TMV concentration as reported in the previous paper (Omura, 1978). The plants grown in $12 \mathrm{~cm}$ pots in greenhouse for $60-80$ days were moved to a greenhouse air-conditioned at $25^{\circ} \mathrm{C}$, a week before inoculation, and the tip and lower leaves were cut off leaving four fully expanded leaves three days before inoculation. Small piece from the peripheral tissue of each callus was weighed and homogenized with mortar and pestle and was appropriately diluted with distilled water. Five hundred-fold (W/V) diluted suspension was commonly inoculated. Inoculation was made by cotton swabs on half leaves of $\mathrm{N}$. glutinosa dusted with 400 mesh carborandum. Purified TMV, the concentrations of which were ex- 
pected to produce 50-150 local lesions on a half-leaf, was simultaneously inoculated on the opposite half-leaves as a control. Eight leaves were used for each specimen. Local lesions were counted three days after inoculation. All the experiments were repeated three times.

\section{RESULTS}

Effect of plant hormones on the growth and appearance of tobacco tissue culture

The tissue pieces obtained aseptically from the peripheral part of a stock callus were transferred on the test media containing NAA 0.01-40 mg/l and kinetin $\mathrm{O}-2 \mathrm{mg} / \mathrm{l}$ in different combinations. Table 1 shows the color and average fresh weight of ten calli grown on each medium during each generation (30 days). The tissues grew well on the media containing 1 and $10 \mathrm{mg} / 1$ of NAA and the best growth was resulted with the combination of NAA 1-10 $\mathrm{mg} / \mathrm{l}$ and kinetin $0.2 \mathrm{mg} / \mathrm{l}$. Most part of the callus proliferated into green or brown and became compact at $2 \mathrm{mg} / \mathrm{l}$ of kinetin irrespective of NAA concentrations or at relatively low concentrations of NAA irrespective of kinetin concentrations. The inner tissue of these calli was rather translucent. The green and compact peripheral tissue was able to separate easily from the soft translucent inner tissue when calli were grown at the combination of 1 $\mathrm{mg} / 1$ of NAA and 0.02 or $0.2 \mathrm{mg} / 1$ of kinetin. At relatively high concentrations of NAA with relatively low concentrations of kinetin, the callus having translucent peripheral tissue with greenish inner tissue grew. Translucent tissue gradually became whitish in later stage of 30 days incubation period. In general, the green or brown tissue was compact and the translucent tissue was soft and friable.

Table 1. Growth and color of tobacco tissue cultures on the media containing different combinations of plant hormones".

\begin{tabular}{|c|c|c|c|c|c|}
\hline \multirow{2}{*}{ NAA (mg/l) } & \multicolumn{5}{|c|}{ Kinetin $(\mathrm{mg} / \mathrm{l})$} \\
\hline & 0 & 0.002 & 0.02 & 0.2 & 2 \\
\hline 0.01 & $\begin{array}{l}0.2^{22} \\
\mathrm{G}^{32}\end{array}$ & $\begin{array}{c}0.3 \\
T, G^{4)}\end{array}$ & $\begin{array}{l}0.3 \\
B\end{array}$ & $\begin{array}{l}0.2 \\
G\end{array}$ & $\begin{array}{r}0.4 \\
\mathrm{G}, \mathrm{B}\end{array}$ \\
\hline 0.1 & $\begin{array}{r}0.5 \\
\mathrm{G}, \mathrm{T}\end{array}$ & $\begin{array}{r}0.7 \\
r_{2} .0\end{array}$ & $\begin{array}{r}0.7 \\
\text { T. } \\
3.5\end{array}$ & $\begin{array}{l}0.6 \\
G\end{array}$ & ${ }_{\mathbf{G}}^{0.8}$ \\
\hline 1 & $r_{2}^{1.5}$ & $\mathrm{G}, \mathrm{T}$ & T, G & $\begin{array}{r}4.2 \\
\mathrm{~T}_{6} . \sqrt{3}\end{array}$ & $\begin{array}{l}3.2 \\
G\end{array}$ \\
\hline 10 & $\mathrm{G}, \mathrm{T}$ & $B, T$ & $\mathrm{G}, \mathrm{T}$ & $\mathrm{G}, \mathrm{T}$ & ${ }_{G}^{1.0}$ \\
\hline 40 & $\begin{array}{r}0.6 \\
B, T\end{array}$ & $\begin{array}{r}0.4 \\
\text { B. T }\end{array}$ & $\begin{array}{r}0.4 \\
\mathrm{G}, \mathrm{T}\end{array}$ & $\begin{array}{r}0.9 \\
\mathrm{G}, \mathrm{T}\end{array}$ & $\begin{array}{l}0.7 \\
G\end{array}$ \\
\hline
\end{tabular}

1) Basal medium: Murashige and Skoog (1962) medium (free from Edamin, added with $20 \mathrm{~g} / \mathrm{l}$ of sucrose and $6 \mathrm{~g} / \mathrm{l}$ of agar). ${ }^{2)}$ Mean fresh weight of callus at the end of the first generation (generation: 30 days). ${ }^{3)}$ Capital letters show the characteristics of callus. B; brown and compact, G; green and compact, $\mathrm{T}$; translucent and soft. 4) Of two capitals written side by side, the left indicates the characteristics of inner tissue and the right indicates that of peripheral tissue. 
From above results, two series of the combination of NAA and kinetin concentrations, i. e., 0.01-40 mg/1 NAA added with $0.2 \mathrm{mg} / 1 \mathrm{kinetin}$, and 0-2 $\mathrm{mg} / \mathrm{l}$ kinetin added with $1 \mathrm{mg} / \mathrm{l}$ NAA were employed. These series were considered to be sufficient to elucidate the effect of hormones on the nature of the tissue and TMV multiplication.

\section{Effect of NAA on the growth of callus and TMV concentration}

The fresh weight of each callus grown on the medium containing different concentrations of NAA is given in Table 2. The growth patterns were much different depending on the concentrations of NAA. At 0.01 and 0.1 $\mathrm{mg} / 1$ of NAA, the growth of callus during the first generation (30 days) reduced to about $1 / 10$ and $1 / 5$ respectively of that of stock callus and low level of growth lasted till the 6 th generation. At 1,10 and $40 \mathrm{mg} / \mathrm{l}$ of NAA, however, the callus was quickly adapted to the medium and good growth was resulted after the second generation. The calli grown on the medium containing 0.01 or $0.1 \mathrm{mg} / 1 \mathrm{NAA}$ were bright green colored and compact and they sometimes produced leaf primordia. At 10 and $40 \mathrm{mg} / 1$ of NAA, translucent soft tissue developed from the peripheral part of calli and inner part remain-
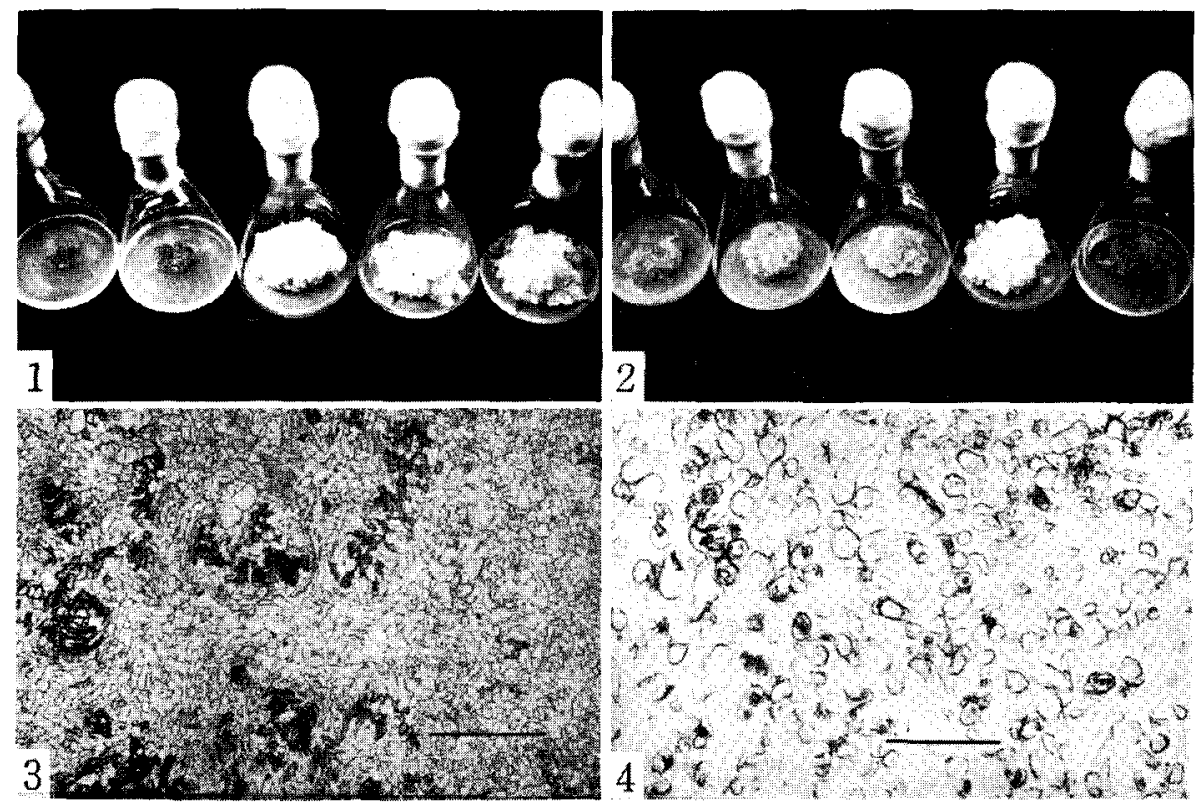

Fig. 1. Calli at the end of the 6th generation on each concentration of NAA added with $0.2 \mathrm{mg} / 1$ of kinetin. From the left, $0.01,0.1,1,10$ and $40 \mathrm{mg} / 1$ of NAA.

Fig. 2. Calli at the end of the 6th generation on each concentration of kinetin added with $1 \mathrm{mg} /$ of NAA. From the left, 0, 0.002, 0.02, 0.2 and $2 \mathrm{mg} / 1$ of kinetin.

Fig. 3. Section of peripheral tissue of stock callus. Scale indicates $500 \mu$. Fig. 4. Section of a callus grown for 6 generations on the media containing $40 \mathrm{mg} / 1$ of NAA and $0.2 \mathrm{mgjl}$ of kinetin. Scale indicates $500 \mu$. 
Table 2. Effect of NAA on the growth of tobacco tissue culture".

\begin{tabular}{|c|c|c|c|c|c|c|}
\hline \multirow{2}{*}{$\begin{array}{l}\text { NAA conc. } \\
(\mathrm{mg} / \mathrm{l})\end{array}$} & \multicolumn{6}{|c|}{ Generation $^{2)}$} \\
\hline & 1 & 2 & 3 & 4 & 5 & 6 \\
\hline 0.01 & $\begin{array}{l}0.43 \\
0.8\end{array}$ & $\begin{array}{l}0.4- \\
0.9\end{array}$ & 0.4 & 0.5 & 0.6 & 0.8 \\
\hline 0. 1 & $\begin{array}{l}0.0 \\
3.9\end{array}$ & 6.6 & $\begin{array}{l}1.0 \\
8.7\end{array}$ & 9.9 & $\begin{array}{l}1.1 \\
9.7\end{array}$ & 9.7 \\
\hline 10 & $6: 5$ & 8.9 & 9.5 & 9.3 & 8.9 & 9.4 \\
\hline 40 & 0.9 & 9.8 & 9.1 & 8.9 & 9.4 & 8.9 \\
\hline
\end{tabular}

1) Kinetin concentration in the medium was $0.2 \mathrm{mg} / \mathrm{l}$.

2) About $100 \mathrm{mg}$ of translucent tissue was transferred every 30 days.

3) Mean fresh weight ( $g$ ) of callus.

Table 3. Effect of NAA on TMV concentration in tobacco tissue culture".

\begin{tabular}{|c|c|c|c|c|c|}
\hline \multirow{2}{*}{$\begin{array}{l}\text { NAA conc. } \\
(\mathrm{mg} / \mathrm{l})\end{array}$} & \multirow{2}{*}{ Exp. no. } & \multicolumn{4}{|c|}{ Generation*) } \\
\hline & & 0 & 2 & 4 & 6 \\
\hline 0.01 & $\begin{array}{l}1 \\
2 \\
3\end{array}$ & & $\begin{array}{l}1053 \\
106 \\
47\end{array}$ & $\begin{array}{r}120 \\
102 \\
88\end{array}$ & $\begin{array}{r}77 \\
143 \\
42\end{array}$ \\
\hline 0.1 & $\begin{array}{l}1 \\
2 \\
3\end{array}$ & & $\begin{array}{r}125 \\
104 \\
81\end{array}$ & $\begin{array}{r}117 \\
64 \\
70\end{array}$ & $\begin{array}{l}70 \\
21 \\
16\end{array}$ \\
\hline 1 & $\begin{array}{l}1 \\
2 \\
3\end{array}$ & $\begin{array}{l}100 \\
100 \\
100\end{array}$ & $\begin{array}{r}140 \\
73\end{array}$ & $\begin{array}{r}14 \\
13 \\
4\end{array}$ & $\begin{array}{l}1 \\
2 \\
0\end{array}$ \\
\hline 10 & $\begin{array}{l}1 \\
2 \\
3\end{array}$ & & $\begin{array}{l}2 \\
4 \\
0\end{array}$ & $\begin{array}{l}5 \\
1 \\
3\end{array}$ & $\begin{array}{l}3 \\
1 \\
0\end{array}$ \\
\hline 40 & $\begin{array}{l}1 \\
2 \\
3\end{array}$ & & $\begin{array}{l}5 \\
0 \\
1\end{array}$ & $\begin{array}{l}2 \\
1 \\
0\end{array}$ & $\begin{array}{l}1 \\
1 \\
0\end{array}$ \\
\hline
\end{tabular}

1) See Table 2. 2) See Table 2. 3) Relative TMV concentration at the end of each generation as compared to that in stock callus.

ed greenish and relatively compact. Fig. 1 shows the calli grown on the media containing different concentrations of NAA at the end of the 6th generation.

TMV concentrations in the calli were assayed every two transfers. As shown in Table 3, TMV activity diminished markedly during successive generations correlating with NAA concentrations, $i$. e., it was maintained at high level for long period at 0.01 and $0.1 \mathrm{mg} / \mathrm{l}$ of NAA, but it fell rapidly at 1,10 and $40 \mathrm{mg} / 1$ of NAA. Although TMV concentration fell most rapidly at 10 and $40 \mathrm{mg} / 1$ of NAA, it was maintained in detectable level in some callus tissues even at the end of 6 th generation.

Effect of kinetin on the growth of callus and TM V concentration

Growth of the callus on the medium containing kinetin at different con- 
centrations of $0-2 \mathrm{mg} / 1$ with $1 \mathrm{mg} / \mathrm{l}$ of NAA is given in Table 4 . During the first generation on the medium free from kinetin, the growth reduced to about $1 / 3$ of that of stock callus. The best growth of the callus was observed in every generations at $0.2 \mathrm{mg} / 1$ of kinetin. The type of calli was markedly affected by concentration of kinetin. The calli grown at 0 and $0.002 \mathrm{mg} / \mathrm{l}$ of kinetin were composed of translucent and soft peripheral layer with greenish and relatively compact inner tissue at the end of the first generation and it became completely translucent and friable at the end of the 6 th generation (Fig. 2). The calli grown at 0.02 and $0.2 \mathrm{mg} / 1$ of kinetin were composed of translucent and soft inner tissue with green and compact peripheral tissue and whole body became translucent and soft when inner tissue was used for every transfer. At $2 \mathrm{mg} / 1$ of kinetin, the callus was green and compact in appearance till the 6 th generation even though the softest tissue was used for every transfer.

Table 4. Effect of kinetin on the growth of tobacco tissue culture ${ }^{1)}$.

\begin{tabular}{ccccccc}
\hline \multirow{2}{*}{$\begin{array}{c}\text { Kinetin conc. } \\
\text { (mg/1) }\end{array}$} & \multicolumn{7}{c}{ Generation $^{2)}$} \\
\cline { 2 - 6 } & 1 & 2 & 3 & 4 & 5 & 6 \\
\hline 0 & $1.7^{3)}$ & 2.1 & 2.6 & 4.4 & 5.0 & 5.2 \\
0.002 & 3.2 & 3.5 & 4.6 & 5.2 & 5.6 & 4.8 \\
0.02 & 3.6 & 4.4 & 5.4 & 5.9 & 6.0 & 5.8 \\
0.2 & 4.2 & 7.0 & 8.3 & 9.7 & 9.6 & 9.7 \\
2 & 3.3 & 3.8 & 4.4 & 5.1 & 5.4 & 5.5
\end{tabular}

1) NAA concentration in the medium was $1 \mathrm{mg} /$ (.) $^{(3)}$ See Table 2.

Table 5. Effect of kinetin on TMV concentration in tobacco tissue culture ${ }^{1)}$.

\begin{tabular}{|c|c|c|c|c|c|}
\hline \multirow{2}{*}{$\begin{array}{l}\text { Kinetin conc. } \\
(\mathrm{mg} / \mathrm{l})\end{array}$} & \multirow{2}{*}{$\begin{array}{c}\text { Exp. } \\
\text { no. }\end{array}$} & \multicolumn{4}{|c|}{ Generation ${ }^{2)}$} \\
\hline & & 0 & 2 & 4 & 6 \\
\hline 0 & $\begin{array}{l}1 \\
2 \\
3\end{array}$ & & $\begin{array}{c}0^{3)} \\
8 \\
10\end{array}$ & $\begin{array}{l}0 \\
0 \\
0\end{array}$ & $\begin{array}{l}0 \\
0 \\
0\end{array}$ \\
\hline 0.002 & $\begin{array}{l}\mathrm{a} \\
3\end{array}$ & & $\begin{array}{r}29 \\
0 \\
4\end{array}$ & $\begin{array}{l}0 \\
0 \\
0\end{array}$ & $\begin{array}{l}0 \\
0 \\
0\end{array}$ \\
\hline 0.02 & $\begin{array}{l}1 \\
2 \\
3\end{array}$ & & $\begin{array}{l}25 \\
13 \\
14\end{array}$ & $\begin{array}{l}1 \\
0 \\
2\end{array}$ & $\begin{array}{l}0 \\
0 \\
0\end{array}$ \\
\hline 0.2 & $\begin{array}{l}1 \\
\mathbb{2}\end{array}$ & $\begin{array}{l}100 \\
100\end{array}$ & $\begin{array}{r}75 \\
1 B 3\end{array}$ & $\begin{array}{l}10 \\
28\end{array}$ & $\begin{array}{l}1 \\
0 \\
0\end{array}$ \\
\hline 2 & $\begin{array}{l}1 \\
2 \\
3\end{array}$ & & $\begin{array}{l}149 \\
120 \\
143\end{array}$ & $\begin{array}{r}190 \\
145 \\
88\end{array}$ & $\begin{array}{r}187 \\
104 \\
88\end{array}$ \\
\hline
\end{tabular}

1) See Table 4. 2) See Table 2. 3) See Table 3. 
TMV concentration in callus tissue was assayed every two transfers. Table 5 shows the trends of TMV concentration in the tissues cultured on the media containing different concentrations of kinetin (O-2 mg/l) added with $1 \mathrm{mg} / \mathrm{l}$ of NAA. TMV concentration decreased rapidly at lower concentrations of kinetin. TMV concentration in the tissue grown on the medium containing kinetin less than $0.002 \mathrm{mg} / 1$ fell markedly with increase of generations and no longer was detected beyond the 4 th generation. At $2 \mathrm{mg} / \mathrm{l}$ of kinetin, however, no decreasing effect was observed.

\section{Histological observation of the callus}

Frozen sections of the calli grown at different hormonal conditions were made at the end of the 6 th generation to compare with those of stock callus. Most area of the peripheral tissue of stock callus consisted of compactly arranged small cells, and many tracheid-like structures were observed (Fig. 3). The callus tissues grown on 0.01 and $0.1 \mathrm{mg} / 1$ of NAA added with $0.2 \mathrm{mg}$ $/ 1$ of kinetin were composed of the cells much different in size, associating tightly with each other in some areas. In most cases, the callus grown at $40 \mathrm{mg} / 1$ of NAA and $0.2 \mathrm{mg} / 1$ of kinetin was composed of loosely arranged large cells (Fig. 4) as in the case of the tissues grown at $10 \mathrm{mg} / \mathrm{l}$ of NAA with $0.2 \mathrm{mg} / \mathrm{l}$ of kinetin.

The callus cultured for 6 generations at $0,0.002,0.02$ or $0.2 \mathrm{mg} / 1 \mathrm{kinetin}$ added with $1 \mathrm{mg} / 1$ of NAA was composed of cells larger and less associated than those in the callus grown at $40 \mathrm{mg} / \mathrm{l}$ of NAA and $0.2 \mathrm{mg} / \mathrm{l}$ of kinetin (Fig. 4). On the other hand, the callus grown for 6 generations at $2 \mathrm{mg} / 1 \mathrm{of}$ kinetin with $1 \mathrm{mg} / 1$ of NAA was composed of the cells varied in size tightly associating in most areas, which was similar to those grown at 0.01 and 0.1 $\mathrm{mg} / 1$ of NAA added with $0.2 \mathrm{mg} / 1$ of kinetin.

Effect of NAA on the growth of callus and TMV concentration under the kinetin-free conditions

Since the maintenance of TMV activity in tobacco callus was highly correlated with kinetin concentration in the medium (Table 5), growth of the callus and change of TMV concentration were examined on purpose with kinetin free medium.

At $0.01 \mathrm{mg} / 1$ of NAA, tissue became brown and did not grow beyond the 3 rd transfer. At $0.1 \mathrm{mg} / 1$ of NAA, watery soft tissue developed at first, but grew poor after that, and finally they became brown at the end of each generation. At 1, 10 and $40 \mathrm{mg} / 1$ of NAA, tissue proliferated rapidly to make friable soft callus after the 2 nd or 3 rd transfer. TMV concentration fell sharply during the first and 2 nd generation and no longer be detected beyond the $3 \mathrm{rd}$ or 4 th generation in the friable tissues.

\section{DISCUSSION}

Tobacco callus tissue infected with TMV 'was reported to be consisted of a mixture of the infected and healthy cells (Hansen and Hildebrandt, 1966). 
According to the previous work carried out by fluorescent antibody method, TMV was unevenly distributed in the infected callus corresponding with compactness of the tissue or distribution frequency of tracheid-like structures (Omura, 1978). TMV concentration in these tissues usually ran parallel with the frequency of the infected cells (Omura, 1978). Furthermore, it was also elucidated that TMV concentration was maintained for many generations by successive transfers of green compact tissues, while it decreased rapidly if translucent soft tissues were successively transferred (Omura, 1978). The medium containing either lower level of kinetin or higher level of NAA made callus tissue translucent and soft, while opposite hormonal conditions made it green and compact (Table 1), coinciding with the results obtained by previous workers (Fossard et al., 1974; Linsmaier and Skoog, 1965; Nishiyama and Taira, 1966; Vasil and Hildebrandt, 1967). TMV concentration was decreased rapidly in the callus grown under the former condition, whereas it was maintained for many years under the latter condition (Table 3, 5). The most rapid decrease was observed in the callus grown on kinetin-free medium (Table 5).

The reasons why TMV concentration decreases so rapidly in the translucent soft tissue grown on the media containing hormones at optimum concentrations are yet obscure. Milo and Srivastava (1969b) reported that TMV multiplication in tobacco callus was strongly inhibited at $0.2 \mathrm{mg} / \mathrm{l}$ of kinetin. In our experiment, however, TMV concentration was maintained at a constant level for over 80 generations in stock callus on the medium containing $0.2 \mathrm{mg} / 1$ of kinetin and $1 \mathrm{mg} / 1$ of NAA so far as green compact tissue was used for every transfer. Furthermore, TMV concentration in the originally transplanted pith tissue did not decrease at all at the end of the first generation. These results suggest that direct inactivation effect of plant hormones on TMV will be negligible.

As reported previously, TMV is unevenly distributed in tobacco callus tissue, correlating with compactness of cell arrangement (Omura, 1978). The effect of plant hormones on TMV concentration in callus tissue seems not to be caused by direct manner but by shifting the compactness of cell arrangement in the tissue.

For the purpose of eliminating virus from virus-infected plant tissue through callus tissue, the successive transfers of translucent tissue on the medium containing higher concentration $(10,40 \mathrm{mg} / \mathrm{l})$ of NAA with lower concentration (O-O. $02 \mathrm{mg} / 1$ ) of kinetin should be recommended.

\section{ACKNOWLEDGMENTS}

The authors are grateful to Dr. Z. Hidaka, for his encouragement during this work.

\section{REFERENCES}

Aldwinckle, H. S. and I. W. Selman 1967 Some effects of supplying benzyladenine to leav- 
es and plants inoculated with viruses. Ann. Appl. Biol., 60: 49-58

Aldwinckle, H. S. 1975 Stimulation and inhibition of plant virus replication in uivo by 6-benzylaminopurine. Virology, $66: 341-343$

Cheo. P. C. 1969 Effect of 2, 4-dichlorophenoxyacetic acid on tobacco mosaic virus infection. Phytopathology, $59: 243-244$

Daft, M. J. 1965 Some interactions of kinetin and temperature on tobacco leaves infected with tomato aucuba mosaic virus. Ann. Appl.Biol., 55: 51-56

Fossard, R. A., A. Myint, and E. C. M. Lee 1974 A broad spectrum tissue culture experiment with tobacco (Nicotiana tabacum) pith tissue callus. Physiol. Plantarum, 31: 125-130

Gondo, M. 1953 Effect of plant hormones on tobacco mosaic symptoms (1). Ann. Phytopath. Soc. Japan, 18: 22-24

Hansen, A. J. and A. C. Hildebrandt 1966 The distribution of tobacco mosaic virus in plant callus cultures. Virology, 28: 15-21

Hariharasubramanian, V 1968 The effect of 8-azaguanine,2-thiouracil, and 2, 4-dichlorophenoxyacetic acid on the multiplication and infectivity of Dolichos enation mosaic virus. Phytopathol. Z., 62: 92-99

Kiraly, Z., M. El Hammady. and B. I. Pozsar 1968 Susceptibility to tobacco mosaic virus in relation to RNA and protein synthesis in tobacco and bean plants. Phytopathol. Z., 63: $47-63$

Kiraly, Z and J. Szirmai 1964 The influence of kinetin on tobacco mosaic virus production in Nicotiana glutinosa leaf disks. Virology, $23: 286-288$

Kutsky, R. 1952 Effects of indolebutyric acid and other compounds on virus concentration in plant tissue cultures. Science. 115: 19-20

Kutsky, R. J. and T. E. Rawlins 1950 Inhibition of virus multiplication by naphthalene acetic acid in tobacco tissue cultures as revealed by a spectrophotometric method. $J$. Bacteriology. $60: 763-766$

Linsmaier, E. M. and F. Skoog 1965 Organic growth factor requirements of tobacco tissue cultures. Physiol. Plantarum, $18: 100-127$

Miller, C. 0.. F. Skoog, M. H. Von Saltza and F. M. Strong 1955 Kinetin, a cell division factor from deoxyribonucleic acid. J. Am. Chem. Soc., 77: 1392

Milo, G. E. and B. I. S. Srivastava 1969a Effect of cytokinins on tobacco mosaic virus production in local-lesion and systemic hosts. Virology. 38: 26-31

Milo, G. E. and B. I. S. Srivastava 1969b Effect of cytokinins on tobacco mosaic virus production in tobacco pith tissue cultures. Virology, 39: 621-623

Murashige. T. and F. Skoog 1962 A revised medium for rapid growth and bioassays with tobacco tissue cultures. Physiol. Plantarum, 15: 473-497

Nakagaki. Y. 1971 Effect of kinetin on local lesion formation on detached bean leaves inoculated with tobacco mosaic virus or its nucleic acid. Ann. Phytopath. Soc. Japan, $37: 307309$

Nishiyama, I. and T. Taira 1966 The effects of kinetin and indoleacetic acid on callus growth and organ formation in two species of Nicotiana. Japan. J. Genetics, 41: 357-365

Omura. T. 1978 Localization of tobacco mosaic virus in tobacco callus tissue. Ann. Phytopath. Soc. Japan (In press)

Selman, I. W. 1964 The effect of kinetin on infection of petunia and tomato leaves with tomato spotted-wilt virus. Ann. Appl. Biol., 53: 67-76

Simons, T. J., H. W. Israel and A. F. Ross 1972 Effect of 2, 4-dichlorophenoxyacetic acid on tobacco mosaic virus lesions in tobacco and on the fine structure of adjacent cells. Virology, 48: 502-515

Vasil, V. and A. C. Hildebrandt 1967 Further studies on the growth and differentiation of single, isolated cells of tobacco in vitro. Plnata, 75: 139-151 